\title{
Thermal Stability and Mechanical Properties of Cu-Based Bulk Glassy Alloys in $\mathrm{Cu}_{50}\left(\mathrm{Zr}_{1-x} \mathrm{Hf}_{x}\right)_{45} \mathrm{Al}_{5}$ System
}

\author{
Wei Zhang ${ }^{1}$ and Akihisa Inoue ${ }^{2}$ \\ ${ }^{1}$ Japan Science and Technology Corporation, Sendai 980-8577, Japan \\ ${ }^{2}$ Institute for Materials Research, Tohoku University, Sendai 980-8577, Japan
}

\begin{abstract}
The thermal stability, crystallization and mechanical properties of the $\mathrm{Cu}_{50}\left(\mathrm{Zr}_{1-x} \mathrm{Hf}_{x}\right)_{45} \mathrm{Al}_{5}(x=0$ to 1$)$ bulk glassy alloys have been investigated. The glass transition temperature $\left(T_{\mathrm{g}}\right)$, crystallization temperature $\left(T_{\mathrm{x}}\right)$, liquidus temperature $\left(T_{1}\right)$ and the supercooled liquid region $\Delta T_{\mathrm{x}}\left(=T_{\mathrm{X}}-T_{\mathrm{g}}\right)$ increase with increasing Hf content. The reduced glass transition temperature $\left(T_{\mathrm{g}} / T_{1}\right)$ is in the range from 0.603 to 0.615 . The Vicker's hardness $(H \mathrm{v})$, Young's modulus $(E)$ and compressive fracture strength $\left(\sigma_{\mathrm{c}, \mathrm{f}}\right)$ of the bulk glassy alloys increase linearly with increasing $\mathrm{Hf}$ content and reach the maximum values of $627,121 \mathrm{GPa}$ and $2262 \mathrm{MPa}$, respectively, for $\mathrm{Cu}_{50} \mathrm{Hf}_{45} \mathrm{Al}_{5}$. A different crystallization behavior is observed for $\mathrm{Cu}_{50} \mathrm{Zr}_{45} \mathrm{Al}_{5}$ and $\mathrm{Cu}_{50} \mathrm{Hf}_{45} \mathrm{Al}_{5}$ glassy alloys. The final crystallization phases are $\mathrm{Cu}_{10} \mathrm{Zr}_{7}$ for the former alloy, and $\mathrm{Cu}_{10} \mathrm{Hf}_{7}$ and $\mathrm{CuHf}_{2}$ for the latter alloy.
\end{abstract}

(Received July 7, 2003; Accepted August 27, 2003)

Keywords: copper-zirconium-aluminum alloy, hafnium addition, thermal stability, bulk glassy alloy, mechanical property, crystallization

\section{Introduction}

It is known that amorphous alloys have characteristic physical and chemical properties such as high strength, high corrosion resistance and good soft magnetic properties, which are significantly different from those of the corresponding crystalline alloys. ${ }^{1)}$ However, the requirement of rapid solidification has lead to strict limitation of their material shape to ribbon, wire and powder and its limitation has restricted further extension of their application fields. Since the findings of glassy-type alloys with a large supercooled liquid region in $\mathrm{Mg}-\mathrm{Ln}-\mathrm{Ni}^{2)}$ and $\mathrm{Ln}-\mathrm{Al}-\mathrm{Ni}^{3)}(\mathrm{Ln}=\mathrm{lan}-$ thanide metals) systems, followed by the successes of producing bulk glassy alloys in the $\mathrm{Ln}_{-}^{-}$) and $\mathrm{Mg}_{-}{ }^{5}$ ) based systems by the copper mold casting method, much attention has been paid to the development of new glassy alloys with high glass-forming ability (GFA). As a result, bulk glassy alloy systems have been widely extended to $\mathrm{Zr}-,{ }^{6,7)} \mathrm{Fe}-,{ }^{8)} \mathrm{Pd}-$ $\mathrm{Cu}-,{ }^{9)} \mathrm{Co}-,{ }^{10)} \mathrm{Cu}-\mathrm{Ti}_{-},{ }^{11)} \mathrm{Ni}-\mathrm{Zr}^{-}{ }^{12)}$ and $\mathrm{Ni}-\mathrm{Nb}^{13-15)}$ based alloys. Recently, we have succeeded in developing new $\mathrm{Cu}$ based bulk glassy alloys in $\mathrm{Cu}-\mathrm{Zr}-\mathrm{Ti}$ and $\mathrm{Cu}-\mathrm{Zr}-\mathrm{Al}$ systems. ${ }^{16,17)}$ The $\mathrm{Cu}-\mathrm{Zr}$-Al glassy alloys have the following advantage points, e.g., (1) high glass-forming ability leading to the maximum sample diameter of over $3 \mathrm{~mm}$, (2) appearance of a large supercooled liquid region exceeding $70 \mathrm{~K}$ leading to warm-working through viscous flow of supercooled liquid, ${ }^{18)}$ (3) high fracture strength above $1885 \mathrm{MPa}$, and (4) higher mass density which is effective for enhancement of the penetrative property. ${ }^{19)}$

Further improvement in characteristics of the $\mathrm{Cu}-\mathrm{Zr}-\mathrm{Al}$ glassy alloys may be possible by addition of alloying elements. Hafnium is chemically analogous to zirconium, though its atomic weight bis much larger. Thus, it is speculated that the alloys in which $\mathrm{Zr}$ is replaced by $\mathrm{Hf}$ would increase density in conjunction with excellent GFA. It has been reported that $\mathrm{Zr}$-based bulk glassy alloys in which $\mathrm{Zr}$ is replaced by $\mathrm{Hf}$ possess increased mechanical properties. $^{20)}$ However, little is known about the effect of substitution of $\mathrm{Hf}$ for $\mathrm{Zr}$ on the thermal stability and mechanical properties of $\mathrm{Cu}$-based $\mathrm{Cu}-\mathrm{Zr}-\mathrm{Al}$ bulk glassy alloys. This paper presents the density, thermal stability and mechanical properties of the $\mathrm{Cu}_{50}\left(\mathrm{Zr}_{1-x} \mathrm{Hf}_{x}\right)_{45} \mathrm{Al}_{5} \quad(x=0$ to1) glassy alloys and to investigate the effectiveness of substitution of $\mathrm{Hf}$ for $\mathrm{Zr}$.

\section{Experimental Procedure}

Multi-component $\mathrm{Cu}$-based $\mathrm{Cu}-(\mathrm{Hf}, \mathrm{Zr})-\mathrm{Al}$ alloy ingots were prepared by arc melting the mixtures of pure $\mathrm{Cu}, \mathrm{Zr}$, Hf and $\mathrm{Al}$ metals in a Ti-gettered argon atmosphere. The purity of metals was over 99.9 mass \%. Alloy ingots were re-melted four times to ensure chemical homogeneity. The mass losses were measured for each ingot after melting and were less than 0.1 mass $\%$. The glassy alloys in a ribbon form with a cross section of $0.02 \times 1.5 \mathrm{~mm}^{2}$ and in a cylindrical rod form with a diameter of $2 \mathrm{~mm}$ were produced by melt spinning and copper mold casting, respectively. The glassy phase was identified by X-ray diffraction and thermal stability was examined by differential scanning calorimetry (DSC) at a heating rate of $0.67 \mathrm{~K} / \mathrm{s}$. The melting and liquidus temperatures were measured with a differential thermal analyzer (DTA) at a heating rate of $0.17 \mathrm{~K} / \mathrm{s}$. The density was measured by Archimedes' principle by weighing ingots in toluene and in air. Vicker's hardness was measured using a microhardness tester under a load of $200 \mathrm{~g}$. Mechanical properties were measured under a compressive load with an Instron testing machine. The gauge dimension of specimens was $2 \mathrm{~mm}$ in diameter and $4 \mathrm{~mm}$ in height and the strain rate was $5 \times 10^{-4} \mathrm{~s}^{-1}$. The fracture surface was examined by scanning electron microscopy (SEM).

\section{Results}

The X-ray diffraction patterns showed all that the meltspun $\mathrm{Cu}_{50}\left(\mathrm{Zr}_{1-x} \mathrm{Hf}_{x}\right)_{45} \mathrm{Al}_{5}$ ( $x=0$ to 1 ) alloy ribbons were composed of a glassy single phase. Figure 1 shows DSC (a) 

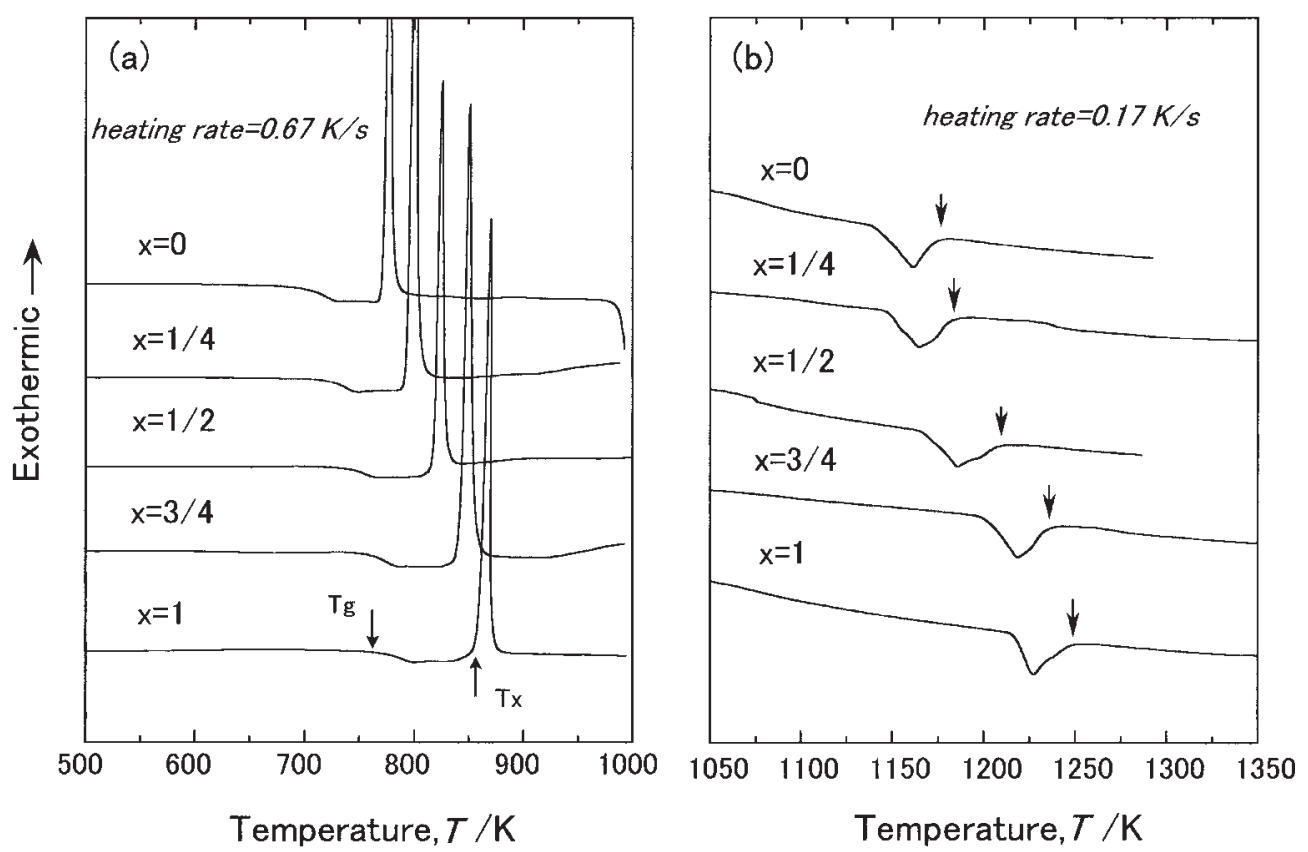

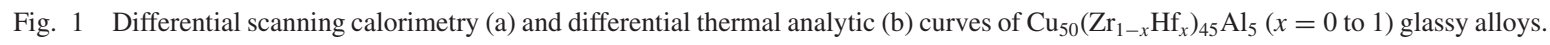

and DTA (b) curves of the melt-spun $\mathrm{Cu}_{50}\left(\mathrm{Zr}_{1-x} \mathrm{Hf}_{x}\right)_{45} \mathrm{Al}_{5}$ $(x=0,1 / 4,1 / 2,3 / 4$ and 1$)$ glassy alloys. All alloys exhibit a distinct glass transition, followed by a supercooled liquid region and then a single exothermic reaction due to crystallization. The solidification of those alloys is completed through a single endothermic reaction leading to a lower liquidus temperature. Based on the DSC and DTA curves, glass transition temperature $\left(T_{\mathrm{g}}\right)$ and crystallization temperature $\left(T_{\mathrm{x}}\right)$, supercooled liquid region $\Delta T_{\mathrm{x}}\left(=T_{\mathrm{x}}-T_{\mathrm{g}}\right)$, liquidus temperature $\left(T_{1}\right)$ and reduced glass transition temperature $\left(T_{\mathrm{g}} / T_{1}\right)$ are plotted as a function of $\mathrm{Hf}$ content in Fig. 2. As the Hf content increases, $T_{\mathrm{x}}$ and $T_{\mathrm{g}}$ increase almost linearly and the increase ratio is considerably larger for $T_{\mathrm{x}}$, resulting in a linear increase from $71 \mathrm{~K}$ at $x=0$ to $91 \mathrm{~K}$ at $x=1$. It is thus concluded that the substitution of $\mathrm{Hf}$ for $\mathrm{Zr}$ in the $\mathrm{Cu}-\mathrm{Zr}-\mathrm{Al}$ glassy alloys is effective for an increase in $\Delta T_{\mathrm{x}}$. The $T_{1}$ increases monotonously with increasing $\mathrm{Hf}$ content. However, the $T_{\mathrm{g}} / T_{1}$ gradually increases from 0.603 at $x=0$ to 0.615 at $x=3 / 4$, and then slightly decreases. Here, it is noticed that the large $\Delta T_{\mathrm{x}}$ exceeding $70 \mathrm{~K}$ and high $T_{\mathrm{g}} / T_{1}$ above 0.60 are simultaneously obtained in the Hf content range from $x=0$ to 1 , indicating that $\mathrm{Cu}_{50}\left(\mathrm{Zr}_{1-x} \mathrm{Hf}_{x}\right)_{45} \mathrm{Al}_{5}$ glassy alloys have high thermal stability of the supercooled liquid and high GFA. ${ }^{21)}$

The $\mathrm{Cu}_{50}\left(\mathrm{Zr}_{1-x} \mathrm{Hf}_{x}\right)_{45} \mathrm{Al}_{5}$ ( $x=0$ to 1 ) alloy rods of $2.0 \mathrm{~mm}$ in diameter were formed by copper mold casting. Figure 3 shows X-ray diffraction patterns obtained from the transverse cross-sections of the alloy rods. The X-ray diffraction patterns consist only of broad peaks, indicating the formation of a glassy single phase.

We measured the density of the glassy alloy rods. The density increases linearly with increasing $\mathrm{Hf}$ content from $7.574 \mathrm{~g} / \mathrm{cm}^{3}$ at $x=0$ to $11.508 \mathrm{~g} / \mathrm{cm}^{3}$ at $x=1$. This is consistent with the density which is predicted on the basis of the known density of $\mathrm{Cu}-\mathrm{Zr}$ - $\mathrm{Al}$ alloys, suggesting that the substitution of $\mathrm{Hf}$ for $\mathrm{Zr}$ does not significantly alter the structure of the glassy alloys.

Figure 4 shows the compressive stress-strain curve of the glassy alloys rod of $2.0 \mathrm{~mm}$ in diameter. It is seen that the total strain is less than 0.023 , with plastic strains of 0 to 0.002 , and the fracture strength increases monotonously with increasing $\mathrm{Hf}$ content. Figure 5 shows the changes in compressive Vickers hardness $\left(H_{\mathrm{V}}\right)$, Young's modulus $(E)$ and fracture strength $\left(\sigma_{\mathrm{c}, \mathrm{f}}\right)$ with $\mathrm{Hf}$ content for the $\mathrm{Cu}_{50}\left(\mathrm{Zr}_{1-x} \mathrm{Hf}_{x}\right)_{45} \mathrm{Al}_{5}$ ( $x=0$ to 1 ) glassy alloys. The $H_{\mathrm{V}}, E$ and $\sigma_{\mathrm{c}, \mathrm{f}}$ increase almost linearly from 546, $102 \mathrm{GPa}$ and $1885 \mathrm{MPa}$, respectively, at $x=0$ to $627,121 \mathrm{GPa}$ and $2262 \mathrm{MPa}$, respectively, at $x=1$. We have also confirmed that the fracture occurs along the maximum shear stress plane which is declined by about 45 degrees to the direction of applied compressive load, and the fracture surface consists mainly of a well-developed vein pattern. It is thus also concluded that the substitution of $\mathrm{Hf}$ for $\mathrm{Zr}$ for the $\mathrm{Cu}$ ( $\mathrm{Zr}, \mathrm{Hf})-\mathrm{Al}$ glassy alloys is effective for an increase in mechanical properties.

We have examined crystallization behavior of the $\mathrm{Cu}_{50}\left(\mathrm{Zr}_{1-x} \mathrm{Hf}_{x}\right)_{45} \mathrm{Al}_{5}$ glassy alloys by $\mathrm{X}$-ray diffraction. Figure 6 shows $\mathrm{X}$-ray diffraction patterns of the $\mathrm{Cu}_{50} \mathrm{Zr}_{45} \mathrm{Al}_{5}$ (a) and $\mathrm{Cu}_{50} \mathrm{Hf}_{45} \mathrm{Al}_{5}$ (b) alloys annealed for $600 \mathrm{~s}$ at various temperatures just below and above the crystallization exotherm. The different crystallization behavior was observed for the glassy alloys with $x=0$ and $x=1$. The final crystallization phases are $\mathrm{Cu}_{10} \mathrm{Zr}_{7}{ }^{22)}$ for the former alloy, and $\mathrm{Cu}_{10} \mathrm{Hf}_{7}$ and $\mathrm{CuHf}_{2}{ }^{22)}$ for the latter alloy. However, the primary crystalline phase of all $\mathrm{Cu}_{50}\left(\mathrm{Zr}_{1-x} \mathrm{Hf}_{x}\right)_{45} \mathrm{Al}_{5}$ glassy alloys is the $\mathrm{Cu}_{10}(\mathrm{Zr}, \mathrm{Hf})_{7}$ phase of an orthorhombic $\mathrm{Ni}_{10} \mathrm{Zr}_{7}$ type, suggesting that a similar local atomic configurations are formed in the $\mathrm{Cu}_{50}\left(\mathrm{Zr}_{1-x} \mathrm{Hf}_{x}\right)_{45} \mathrm{Al}_{5}$ glassy alloys. In addition, the precipitation temperature of the $\mathrm{Cu}_{10}(\mathrm{Zr}, \mathrm{Hf})_{7}$ phase increases monotonously with increasing $\mathrm{Hf}$ content. Form Fig. 6, it is seen that the primary $\mathrm{Cu}_{10}(\mathrm{Zr}, \mathrm{Hf})_{7}$ phase was first identified by XRD for $\mathrm{Cu}_{50}\left(\mathrm{Zr}_{1-x} \mathrm{Hf}_{x}\right)_{45} \mathrm{Al}_{5}$ ( $x=0$ and 1) 

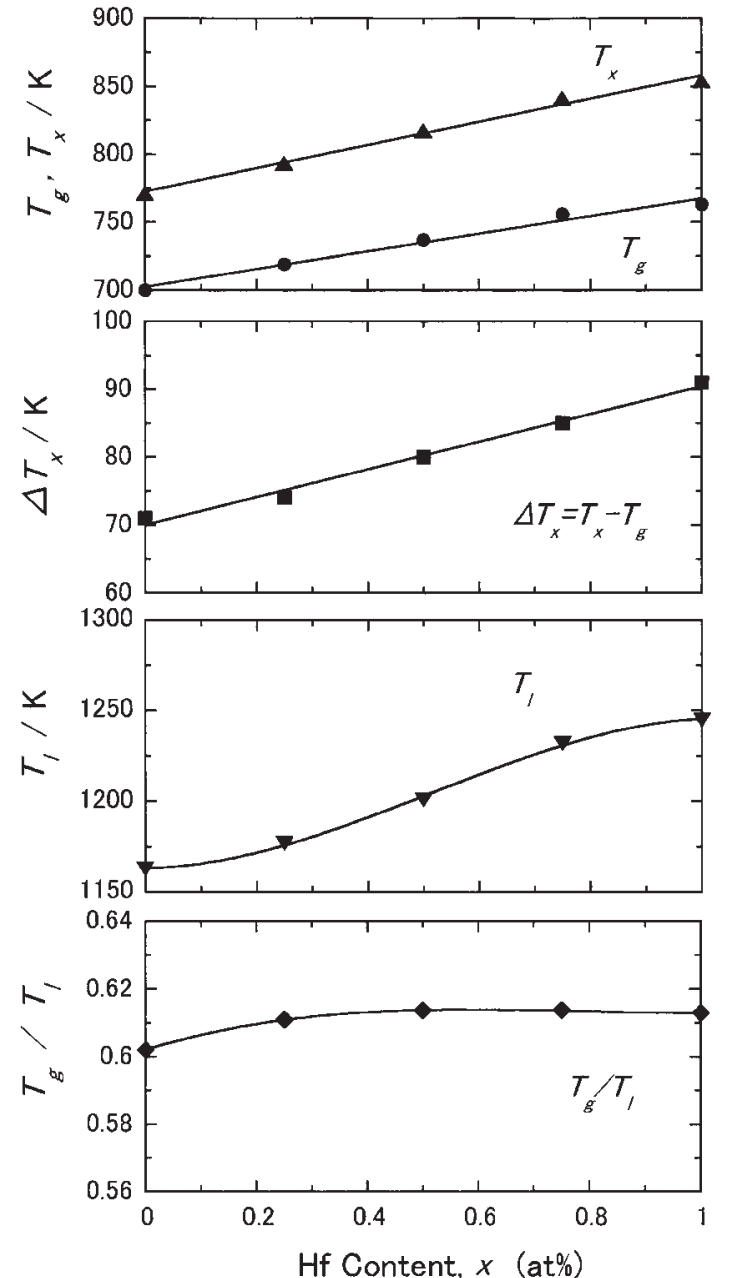

Fig. 2 Glass transition temperature $\left(T_{\mathrm{g}}\right)$, crystallization temperature $\left(T_{\mathrm{x}}\right)$, supercooled liquid region $\left(\Delta T_{\mathrm{x}}=T_{\mathrm{x}}-T_{\mathrm{g}}\right)$, liquidus temperature $\left(T_{1}\right)$ and reduced glass transition temperature $\left(T_{\mathrm{g}} / T_{1}\right)$ as a function of $\mathrm{Hf}$ content for $\mathrm{Cu}_{50}\left(\mathrm{Zr}_{1-x} \mathrm{Hf}_{x}\right)_{45} \mathrm{Al}_{5}$ ( $x=0$ to 1$)$ glassy alloys.

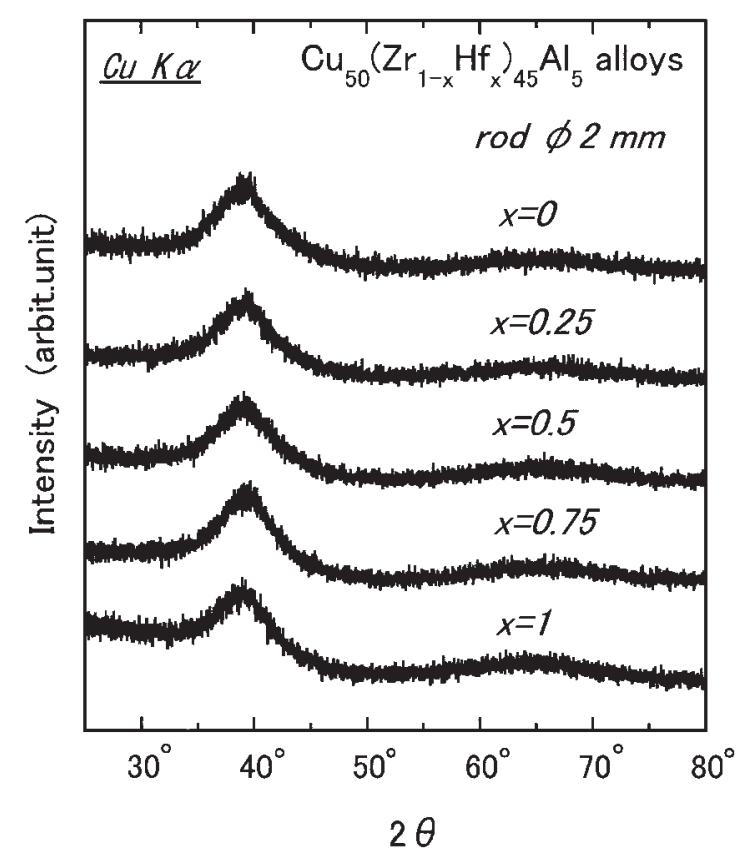

Fig. 3 X-ray diffraction patterns of cast $\mathrm{Cu}_{50}\left(\mathrm{Zr}_{1-x} \mathrm{Hf}_{x}\right)_{45} \mathrm{Al}_{5}$ ( $x=0$ to 1 ) alloy rods with a diameter of $2.0 \mathrm{~mm}$.

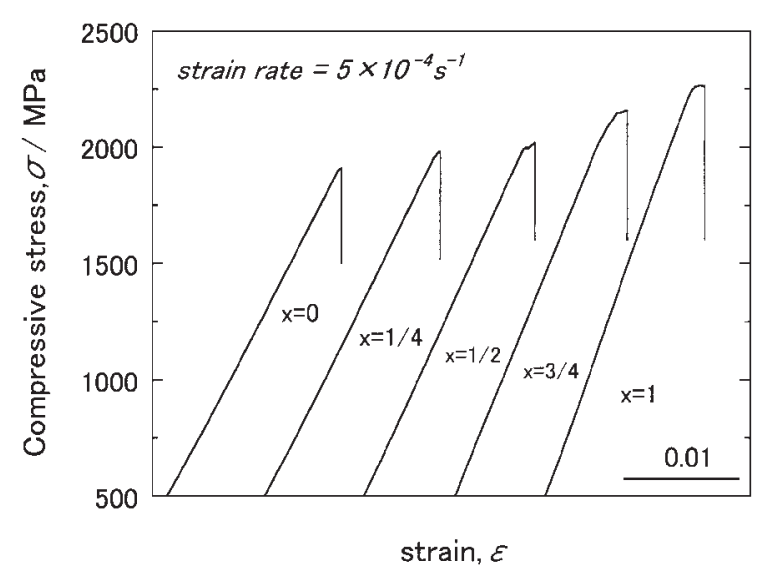

Fig. 4 Compressive stress-elongation curves of $\mathrm{Cu}_{50}\left(\mathrm{Zr}_{1-x} \mathrm{Hf}_{x}\right)_{45} \mathrm{Al}_{5}$ ( $x=0$ to 1$)$ glassy rods with a diameter of $2.0 \mathrm{~mm}$.



Fig. $5 H_{\mathrm{V}}, E$ and $\sigma_{\mathrm{c}, \mathrm{f}}$ as a function of $\mathrm{Hf}$ content for the $\mathrm{Cu}_{50}\left(\mathrm{Zr}_{1-x} \mathrm{Hf}_{x}\right)_{45} \mathrm{Al}_{5}$ ( $x=0$ to 1 ) glassy alloy rods.

glassy alloys annealed for $600 \mathrm{~s}$ at about 723 and $798 \mathrm{~K}$, respectively.

\section{Discussion}

The substitution of $\mathrm{Hf}$ for $\mathrm{Zr}$ in the $\mathrm{Cu}_{50}\left(\mathrm{Zr}_{1-x} \mathrm{Hf}_{x}\right)_{45} \mathrm{Al}_{5}$ glassy alloys increases significantly the supercooled liquid region $\Delta T_{\mathrm{x}}$. This result has a relation to the thermal stability of their glassy alloys against crystallization. The different crystallization behavior was observed for the $\mathrm{Cu}_{50}\left(\mathrm{Zr}_{1-x} \mathrm{Hf}_{x}\right)_{45} \mathrm{Al}_{5}$ glassy alloys, the crystallization of the 

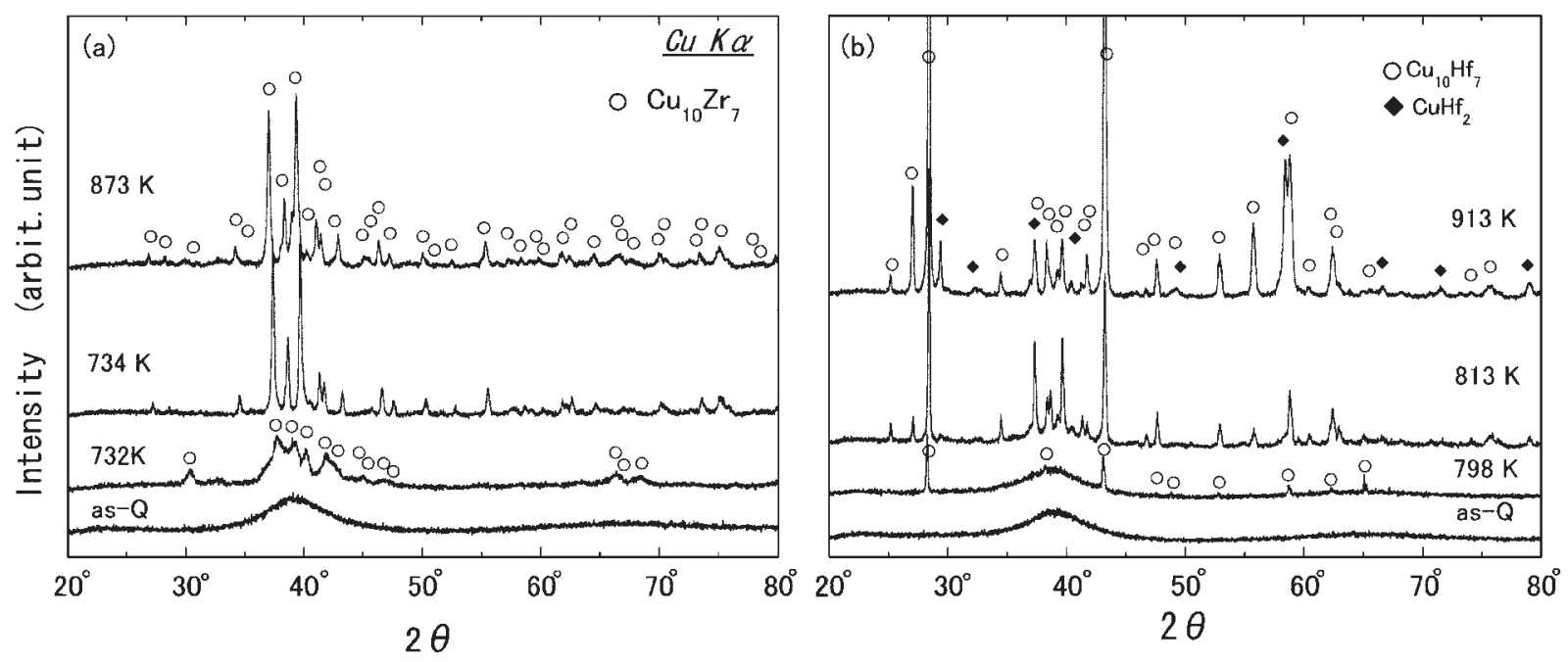

Fig. 6 X-ray diffraction patterns of $\mathrm{Cu}_{50} \mathrm{Zr}_{45} \mathrm{Al}_{5}$ (a) and $\mathrm{Cu}_{50} \mathrm{Hf}_{45} \mathrm{Al}_{5}$ (b) glassy alloys annealed for $600 \mathrm{~s}$ at various temperatures.

glassy alloys occurs through a single exothermic peak corresponding to the reactions of glassy $\rightarrow \mathrm{Cu}_{10} \mathrm{Zr}_{7}$ for $\mathrm{Cu}_{50} \mathrm{Zr}_{45} \mathrm{Al}_{5}$, and glassy $\rightarrow \mathrm{Cu}_{10} \mathrm{Hf}_{7}+$ glassy $\rightarrow \mathrm{Cu}_{10} \mathrm{Hf}_{7}+$ $\mathrm{CuHf}_{2}$ for $\mathrm{Cu}_{50} \mathrm{Hf}_{45} \mathrm{Al}_{5}$. However, the primary crystalline phase of the $\mathrm{Cu}_{50}\left(\mathrm{Zr}_{1-x} \mathrm{Hf}_{x}\right)_{45} \mathrm{Al}_{5}$ glassy alloys is the $\mathrm{Cu}_{10}(\mathrm{Zr}, \mathrm{Hf})_{7}$ phase with an orthorhombic $\mathrm{Ni}_{10} \mathrm{Zr}_{7}$ type structure, and the precipitation temperature of the $\mathrm{Cu}_{10}(\mathrm{Zr}, \mathrm{Hf})_{7}$ phase increases monotonously with increasing Hf content. This indicates that the thermal stability of the glassy alloy against crystallization is enhanced by the increase of Hf content, leading to the increase of $\Delta T_{\mathrm{x}}$.

As shown in Fig. 5, the substitution of $\mathrm{Hf}$ for $\mathrm{Zr}$ in the $\mathrm{Cu}-$ $\mathrm{Zr}-\mathrm{Al}$ glassy alloys is effective for an increase in the mechanical properties. This seems to originate from the change in the bonding force among the constituent elements of the glassy alloys. It is known that the $T_{\mathrm{g}}$ of the glassy alloys reflects the bonding force among the constituent elements. ${ }^{23)}$ The $T_{\mathrm{g}}$ of the $\mathrm{Cu}_{50}\left(\mathrm{Zr}_{1-x} \mathrm{Hf}_{x}\right)_{45} \mathrm{Al}_{5}$ glassy alloys increases linearly with increasing Hf content (Fig. 2), being consistent with the mechanical properties of the glassy alloys.

\section{Summary}

We examined the stability of supercooled liquid, density and mechanical properties of the $\mathrm{Cu}_{50}\left(\mathrm{Zr}_{1-x} \mathrm{Hf}_{x}\right)_{45} \mathrm{Al}_{5}(x=0$ to 1$)$ glassy alloys. The results obtained are summarized as follows.

(1) In the $\mathrm{Cu}_{50}\left(\mathrm{Zr}_{1-x} \mathrm{Hf}_{x}\right)_{45} \mathrm{Al}_{5}$ alloy system, the $T_{\mathrm{g}}, T_{\mathrm{x}}$ and $T_{1}$ increase with increasing Hf content, while the $\Delta T_{\mathrm{x}}$ increases linearly from 71 to $91 \mathrm{~K}$ with increasing $x$ from 0 to 1 . The reduced glass transition temperature $\left(T_{\mathrm{g}} / T_{1}\right)$ is in the range from 0.603 to 0.615 .

(2) The density increases linearly with increasing Hf content, and the increase ratio is $52 \%$ when $\mathrm{Zr}$ is completely replaced by Hf.

(3) The $H_{\mathrm{V}}, E$ and $\sigma_{\mathrm{c}, \mathrm{f}}$ of the bulk glassy alloys increase almost linearly with increasing $\mathrm{Hf}$ content. The $\mathrm{Cu}_{50} \mathrm{Hf}_{45} \mathrm{Al}_{5}$ bulk glassy alloy exhibits good mechanical properties, i.e., Vicker's hardness of 627, Young's modulus of $121 \mathrm{GPa}$, compressive fracture strength of $2262 \mathrm{MPa}$, and plastic elongation of $0.2 \%$.

(4) The different intermetallic phases form upon annealing for the $\mathrm{Cu}_{50} \mathrm{Zr}_{45} \mathrm{Al}_{5}$ and $\mathrm{Cu}_{50} \mathrm{Hf}_{45} \mathrm{Al}_{5}$ glassy alloys, $\mathrm{Cu}_{10} \mathrm{Zr}_{7}$ for the former alloy, and $\mathrm{Cu}_{10} \mathrm{Hf}_{7}$ and $\mathrm{CuHf}_{2}$ for the latter alloy.

\section{REFERENCES}

1) F. E. Luborsky (Ed.): Amorphous Metallic Alloys, (Butterworths, London, 1983) pp. 1-7.

2) A. Inoue, K. Ohtera, K. Kita and T. Masumoto: Jan. J. Appl. Phys. 27 (1988) L2248-L2251.

3) A. Inoue, T. Zhang and T. Masumoto: Mater. Trans., JIM 30 (1989) 965-972.

4) A. Inoue, T. Zhang and T. Masumoto: Mater. Trans., JIM 31 (1990) 425-428.

5) A. Inoue, A. Kato, T. Zhang, S. G. Kim and T. Masumoto: Mater. Trans., JIM 32 (1991) 609-616.

6) A. Inoue, T. Zhang and T. Masumoto: Mater. Trans., JIM 31 (1990) 177-183.

7) A. Peker and W. L. Johnson: Appl. Phys. Lett. 63 (1993) 2342-2344

8) A. Inoue and S. G. Gook: Mater. Trans., JIM 36 (1995) 1180-1183.

9) A. Inoue, N. Nishiyama and T. Matsuda: Mater. Trans., JIM 37 (1996) 181-184.

10) T. Itoi and A. Inoue: Mater. Trans., JIM 41 (2000) 1256-1262.

11) X. H. Lin and W. L. Johnson: J. Appl. Phys. 78 (1995) 5614-5619.

12) S. Yi, T. G. Park and D. H. Kim: J. Mater. Res. 15 (2000) 2425-2430.

13) A. Inoue, W. Zhang and T. Zhang: Mater. Trans. 43 (2002) 1952-1956.

14) W. Zhang and A. Inoue: Scr. Mater. 48 (2003) 641-645.

15) H. Choi-Yim, D. Xu and W. L. Johnson: Appl. Phys. Lett. 82 (2003) 1030-1032.

16) A. Inoue, W. Zhang, T. Zhang and K. Kurosaka: Acta Mater. 49 (2001) 2645-2652.

17) A. Inoue and W. Zhang: Mater. Trans. 43 (2002) 2921-2925.

18) A. Inoue, Y. Kawamura and Y. Saotome: Mater. Sci. Forum. 233-234 (1997) 147-154.

19) R. B. Dandliker, R. D. Conner and W. L. Johnson: J. Mater. Res. 13 (1998) 2896-2901.

20) X. Gu, L. Xing and T. C. Hufnagel: Mat. Res. Soc. Symp. Proc. 644 (2001) L12.16.1-L12.16.5.

21) A. Inoue: Acta Mater. 48 (2000) 279-306.

22) P. Villars: Pearson's Handbook, Crsytallographic Data, (ASM Intern. Materials Park, Ohio, 1997) p. 1514.

23) H. S. Chen: Rep. Prog. Phys. 43 (1980) 353-432. 